\title{
Perbedaan Model Pembelajaran Air (Auditory, Intellectualy, Repetition) dengan Model Pembelajaran Konvensional terhadap Hasil Belajar Fisika pada Siswa Kelas X SMA Negeri 2 Biromaru
}

\author{
Selviana, I Wayan Darmadi dan Muslimin \\ e-mail: selvianalagarinda@yahoo.com \\ Program Studi Pendidikan Fisika FKIP Universitas Tadulako \\ Jl. Soekarno Hatta Km. 9 Kampus Bumi Tadulako Tondo Palu - Sulawesi Tengah
}

\begin{abstract}
Abstrak - Penelitian ini bertujuan untuk mengetahui ada tidaknya perbedaan hasil belajar fisika antara siswa yang menggunakan model pembelajaran AIR dengan model pembelajaran konvensional. Adapun desain yang digunakan dalam penelitian ini yaitu the non equivalen, Pretest-Postest Design. Populasi dalam penelitian ini adalah seluruh siswa kelas X SMA Negeri 2 Biromaru, dengan sampel penelitian kelas X MIA 1 sebagai kelas eksperimen dengan jumlah siswa 26 orang dan kelas X MIA 2 sebagai kelas kontrol dengan jumlah siswa 25 orang. Hasil analisa data yang diperoleh adalah hasil belajar fisika, pada kelas eksperimen skor rata-ratanya adalah 12,46 dengan standar deviasi 2,56 dan kelas kontrol skor rata-ratanya adalah 9,44 dengan standar deviasi 2,34. Berdasarkan hasil pengujian hipotesis diperoleh $\mathrm{t}$ hitung $=1,78$ sedangkan untuk $\mathrm{t}$ tabel $=1,67$. Hal ini berarti bahwa hasil pengujian hipotesis berada diluar kriteria penerimaan Ho. Terima Ho jika $-1,67<\mathrm{t}<$ 1,67 dan tolak Ho dalam hal lainnya. Jelas bahwa $t$ hitung $=1,78$ berada diluar Ho. Jadi dengan demikian Ho ditolak dengan taraf nyata $a=0,05$ dengan $d k=49$. Sehingga $H_{1}$ diterima. Hal ini menunjukkan bahwa ada perbedaan hasil belajar fisika antara siswa yang menggunakan model pembelajaran AIR dengan model pembelajaran konvensional.
\end{abstract}

Kata Kunci: Model pembelajaran AIR, Model pembelajaran konvensional, hasil belajar fisika.

\section{PENDAHULUAN}

Rendahnya hasil belajar disebabkan oleh penggunaan pola pikir yang rendah pada pembentukan sistem konseptual IPA. Siswa harus dilatih untuk mengkonstruksi pengetahuannya sendiri sehingga pembelajaran yang didapatkan menjadi lebih bermakna dan siswa akan memiliki kemampuan yang baik dalam memecahkan masalah dalam hidup". Pembelajaran IPA seharusnya dilakukan dengan keterampilan proses sesuai dengan hakikat IPA melalui kegiatan eksperimen di laboratorium [1], tetapi sebagian besar guru masih enggan melakukannya dengan alasan tidak adanya fasilitas alat-alat percobaan. Guru dapat melakukan eksperimen dengan menggunakan alat-alat percobaan sederhana buatan sendiri. Selain itu, guru dapat melengkapi peralatan percobaan yang dibuatnya dengan Lembar Kerja Siswa (LKS) karena dengan LKS aktivitas kerja di laboratorium lebih terarah.

Pelaksanaan pembelajaran di lingkungan sekolah merupakan salah satu tugas utama guru dan pembelajaran dapat diartikan sebagai kegiatan yang ditujukan untuk pembelajaran siswa. Proses pembelajaran masih ditemui adanya kecenderungan siswa lebih bersifat pasif sehingga mereka lebih banyak menunggu sajian dari guru daripada mencari dan menemukan sendiri pengetahuan, keterampilan atau sikap yang mereka butuhkan. Dalam proses belajar mengajar, guru sebagai pengajar dan siswa sebagai subyek belajar, dituntut adanya perubahan di dalam pengetahuan, kemampuan, nilai sikap, serta sifat-sifat pribadi, agar proses itu berlangsung dengan efektif dan efisien.

Hasil observasi yang diperoleh dari SMA Negeri 2 Biromaru bahwa kegiatan pembelajaran pada umumnya masih berlangsung dengan menggunakan metode ceramah. Guru lebih banyak menjelaskan dan menerangkan, sehingga siswa hanya mendengarkan dan mencatat apa yang dijelaskan oleh guru. Apabila siswa diberikan latihan di kelas siswa cenderung menunggu jawaban dari teman.Selain itu siswa cenderung 
bermain-main dalam kelas serta tidak serius mengikuti proses belajar. Guru juga kurang memberikan kegiatan yang bersifatnyata seperti demonstrasi alat atau kegiatan praktikum, hal ini disebabkan karena kurangnya keterbatasan alat-alat laboratorium. Sebagai upaya meningkatkan kualitas hasil belajar siswa, aktivitas belajar serta untuk mengembangkan literasi sains dan teknologi siswa, diperlukan penyempurnaan strategi pembelajaran IPA yang sesuai dengan tujuan dan hakikat IPA itu sendiri dengan melengkapi alat-alat laboratorium dan metode yang melibatkan siswa aktif.

Sehubungan dengan hal di atas, maka banyak model pembelajaran yang dapat menjadikan siswa untuk belajar mandiri, kreatif, dan lebih aktif dalam mengikuti kegiatan pembelajaran. Salah satu model pembelajaran yang dapat digunakan dalam strategi pembelajaran fisika yaitu dengan pembelajaran Auditory, Intellectually, Repetition (AIR). Model Pembelajaran AIR itu sendiri adalah suatu bentuk model pembelajaran yang menekankan pada kegiatan belajar siswa, pada saat siswa mendengarkan dan mencatat materi yang dijelaskan oleh guru dimana siswa juga mampu menggunakan intelektualnya dalam memecahkan masalah serta repetisi berupa tugas. Penerapan pembelajaran AIR ini berkembang secara kolaboratif yang diharapkan dapat meningkatkan hasil belajar siswa karena dalam pembelajaran ini siswa tidak akan merasa bosan dengan pembelajaran yang monoton, melainkan dapat menumbuhkan rasa senang bagi siswa dalam mengikuti kegiatan belajar mengajar disekolah karena dalam pembelajaran ini terdapat unsur Auditori, Intelektual, dan Repetisi yang digunakan secara bergantian dan simultan. Selain itu juga dengan pemanfataan LKS yang dimana LKS disini digunakan guru untuk memuat urutan kegiatan dan membuat beberapa pertanyaan-pertanyaan yang bervariasi agar dapat dijadikan sebagai perangkat pembelajaran dan siswa akan terlibat aktif dalam pembelajaran. LKS itu sendiri sebagai pedoman atau lembaran-lembaran yang diberikan kepada siswa sebagai kegiatan dalam melakukan suatu percobaan. LKS merupakan suatu tugas media atau alat yang diberikan kepada siswa untuk mengerjakan pada saat proses pembelajaran berlangsung didalam kelas.

Hasil penelitian[2] menunjukkan bahwa penerapan model pembelajaran AIR dapat meningkatkan kreativitas matematis siswa pada materi geometri dimensi dua. Penggunaan model pembelajaran AIR dalam pembelajaran matematika menemukan bahwa hasil belajar siswa yang menggunakan model pembelajaran AIR lebih baik dibandingkan dengan menggunakan model pembelajaran biasa[3]. Oleh sebab itu peneliti tertarik untuk meneliti tentang Perbedaan Model Pembelajaran AIR (Auditory, Intellectualy, Repetition) dengan Model Pembelajaran Konvensional Terhadap Hasil Belajar Fisika Pada Siswa Kelas X SMA Negeri 2 Biromaru .

\section{METODE PENELITIAN}

Penelitian ini menggunakan metode eksperimen kuasi, dimana desain penelitian yang digunakan adalah "The Non Equivalen Pretest-Posttest Desing" atau Rancangan Pratest-Pascates yang tidak Ekuivalen, yaitu menggunakan kelas-kelas yang sudah ada sebagai kelompoknya, dengan memilih kelaskelas yang sudah ada diperkirakan sama keadaan/kondisinya. Bentuk desainnya disajikan.

TABEL 1. Desain Penelitian Rancangan Prates-Pascates yang tidak Ekuivalen

(the non ekuivalen, Pretest-Postest Design)

\begin{tabular}{|c|c|c|c|}
\hline Kelas & Pretes & Perlakuan & Pascates \\
\hline X MIA 1 & 0 & $X$ & 0 \\
\hline X MIA 2 & 0 & - & 0 \\
\hline
\end{tabular}

Keterangan :

$X$ : Perlakuan untuk kelas eksperimen dengan menggunakan model pembelajaran AIR(Auditory, Intellectualy, Repetition)

$\mathrm{O}$ : Pretest dan postest 


\section{HASIL PENELITIAN DAN PEMBAHASAN}

Pada hasil penelitian ini meliputi hasil selama kegiatan model pembelajaran AIR (Auditory, Intellectualy, Repetition) dan model pembelajaran Konvensional terhadap hasil belajar fisika.Hasil penelitian yang melibatkan dua kelas, yakni kelas eksperimen X MIA 1 dan kelas kontrol $X$ MIA 2 pada SMA Negeri 2 Biromaru[1].

\section{diperoleh.}

Berikut data hasil penelitian yang telah

\section{Hasil Pengolahan Data Penelitian}

Adapun data hasil penelitian untuk kelompok eksperimen dan kelompok kontrol sebagai berikut :

a. Daftar nilai dan frekuensi hasil pretest kelompok eksperimen dan kelompok kontrol.

TABEL 2. Rentang Nilai dan Frekuensi Hasil Pretest hasil belajar

\begin{tabular}{|c|c|c|c|}
\hline Kelompok Eksperimen & \multicolumn{2}{|c|}{ Kelompok Kontrol } \\
\hline Rentang & Frekuensi & Rentang & Frekuensi \\
\hline $2-3$ & 4 & $2-3$ & 3 \\
\hline $4-5$ & 5 & $4-5$ & 6 \\
\hline $6-7$ & 8 & $6-7$ & 9 \\
\hline $8-9$ & 6 & $8-9$ & 4 \\
\hline $10-11$ & 3 & $10-11$ & 3 \\
\hline Jumlah & $\mathbf{2 6}$ & Jumlah & $\mathbf{2 5}$ \\
\hline
\end{tabular}

b. Daftar perbandingan nilai pretest kelompok eksperimen dan kelompok kontrol.

TABEL 3. Nilai Pretest Kelompok Eksperimen dan Kelompok Kontrol

\begin{tabular}{|c|c|c|}
\hline \multirow{2}{*}{ Uraian } & \multicolumn{2}{|c|}{ Kelompok } \\
\cline { 2 - 3 } & Eksperimen & Kontrol \\
\hline Sampel & 26 & 25 \\
Nilai Terendah & 2 & 2 \\
Nilai Tertinggi & 11 & 11 \\
Nilai Rerata & 6,42 & 6,34 \\
\hline
\end{tabular}

c. Daftar nilai dan frekuensi hasil postest kelompok eksperimen dan kelompok kontrol.

TABEL 4. Rentang Nilai dan Frekuensi Hasil Postest Hasil Belajar

\begin{tabular}{|c|c|c|c|}
\hline \multicolumn{2}{|c|}{ Kelompok Eksperimen } & \multicolumn{2}{c|}{ Kelompok Kontrol } \\
\hline Rentang & Frekuensi & Rentang & Frekuensi \\
\hline $8-9$ & 3 & $5-6$ & 3 \\
\hline $10-11$ & 7 & $7-8$ & 4 \\
\hline
\end{tabular}

\begin{tabular}{|c|c|c|c|}
\hline $12-13$ & 8 & $9-10$ & 10 \\
\hline $14-15$ & 4 & $11-12$ & 5 \\
\hline $16-17$ & 4 & $13-14$ & 3 \\
\hline Jumlah & $\mathbf{2 6}$ & Jumlah & $\mathbf{2 5}$ \\
\hline
\end{tabular}

d. Daftar perbandingan nilai posttest kelompok eksperimen dan kontrol.

TABEL 5. Nilai Postest Kelompok Eksperimen dan Kelompok Kontrol

\begin{tabular}{|c|c|c|}
\hline \multirow{2}{*}{ Uraian } & \multicolumn{2}{|c|}{ Kelompok } \\
\cline { 2 - 3 } & Eksperimen & Kontrol \\
\hline Sampel & 26 & 25 \\
Nilai Terendah & 8 & 5 \\
Nilai Tertinggi & 17 & 14 \\
Nilai Rerata & 12.42 & 9,58 \\
\hline
\end{tabular}

\section{Uji Normalitas}

Hasil uji normalitas pretest antara kelompok eksperimen dan kelompok kontrol.

TABEL 6. Hasil Pengujian Normalitas Pretest Kelas Eksperimen dan Kelas Kontrol

\begin{tabular}{|c|c|c|}
\hline \multirow{2}{*}{ Uraian } & \multicolumn{2}{|c|}{ Kelompok } \\
\cline { 2 - 3 } & Eksperimen & Kontrol \\
\hline$X^{2}$ tabel & 5,99 & 5,99 \\
$X^{2}$ hitung & 1,31 & 1,29 \\
\hline
\end{tabular}

Berdasarkan kriteria $\mathrm{X}^{2}$ hitung dan harga $X^{2}$ tabel untuk kelompok eksperimen dan kelompok kontrol ternyata diperoleh $x^{2}$ hitung < $X^{2}$ tabel. Hal ini menunjukkan bahwa kelompok kontrol dan kelompok eksperimen berdistribusi normal.

Hasil uji normalitas posttest antara kelompok eksperimen dan kelompok kontrol.

TABEL 7. Hasil Pengujian Normalitas Posttest kelas Eksperimen dan Kelas Kontrol

\begin{tabular}{|c|c|c|}
\hline \multirow{2}{*}{ Uraian } & \multicolumn{2}{|c|}{ Kelompok } \\
\cline { 2 - 3 } & Eksperimen & Kontrol \\
\hline$X_{\text {tabel }}^{2}$ & 5,99 & 5,99 \\
$X_{\text {hitung }}^{2}$ & 2,08 & 1,87 \\
\hline
\end{tabular}

Berdasarkan kriteria $\mathrm{X}^{2}$ hitung dan harga $\mathrm{X}^{2}$ tabel untuk kelompok eksperimen dan kelompok kontrol ternyata diperoleh $\mathrm{X}^{2}$ hitung $<$ $\mathrm{X}^{2}$ tabel. Hal ini menunjukkan bahwa kelompok kontrol dan kelompok eksperimen berdistribusi normal.

\section{Uji Homogenitas}

Untuk menguji homogenitas varians data tes hasil belajar fisika antara kelas 
eksperimen dan kelas kontrol menggunakan uji Fisher (uji F).

TABEL 8. Uji Homogenitas Data Tes Awal dan Tes Akhir Hasil Belajar Fisikapada Kelas Eksperimen dan Kelas Kontrol

\begin{tabular}{|c|c|c|}
\hline Uraian & Tes awal & Tes akhir \\
\hline$F_{\text {hitung }}$ & 1,43 & 1,19 \\
\hline$F_{\text {tabel }}$ & 1,92 & 1,92 \\
\hline
\end{tabular}

Pada pengujian homogenitas varians data dengan taraf signifikan 0,05 pada kelas eksperimen dan kelas kontrol, nilai $F_{\text {hitung }}$ yang diperoleh untuk tes awal adalah 1,43 dan untuk tes akhir adalah 1,19. Dengan kriteria pengujian $\mathrm{H}_{\circ}$ diterima jika $\mathrm{F}_{(1-\alpha)\left(\mathrm{n}_{1}-1\right)}<\mathrm{F}<$ $\mathrm{F}_{\left(\frac{1}{2} \alpha\right)\left(\mathrm{n}_{1}-1\right)\left(\mathrm{n}_{2}-2\right)}$ Dapat dilihat bahwa $\mathrm{F}_{\text {hitung }}$ berada pada daerah penerimaan $\mathrm{H}_{\circ}$ dengan demikian data tersebut menunjukkan kedua kelas yang dijadikan sampel berasal dari populasi yang homogen.

\section{Uji Hipotesis}

Pengujian hipotesis menggunakan statistik parametrik (uji-t) dua variabel bebas (uji dua pihak) dilakukan setelah diperoleh bahwa hasil data hasil belajar fisika antara kelas eksperimen dan kelas kontrol berdistribusi normal dan homogen.

Hasil perolehan pengujian statistik data hasil belajar fisika antara kelas eksperimen dan kelas eksperimen control.

TABEL 9. Data hasil belajar fisika antara kelas eksperimen dan kelas kontrol

\begin{tabular}{|c|c|c|}
\hline & Tes awal & Tes akhir \\
\hline$t_{\text {hitung }}$ & 0.27 & 1,78 \\
$t_{\text {tabel }}$ & 1,67 & 1,67 \\
Ho & Diterima & Ditolak \\
\hline
\end{tabular}

Pengujian hipotesis yang dilakukan pada taraf signifikan $(\mathrm{a}=0,05)$ dan $\mathrm{dk}=(26+25)-$ $2=49$ dengan kriteria pengujian yakni, $\mathrm{H}_{0}$ diterima jika $-\mathrm{t}_{(1-0,5 a)}<\mathrm{t}<\mathrm{t}_{(1-0,5 \mathrm{a})}$. Untuk pengujian hipotesis berdasarkan tes awal dengan menggunakan rata-rata skor diperoleh $t_{\text {hitung }}=0,27$ dan $t_{\text {tabel }}=1,67$ maka, $H_{0}$ diterima dan hipotesis satu $\left(\mathrm{H}_{1}\right)$ ditolak. Artinya tidak terdapat perbedaan hasil belajar antara kelas eksperimen dan kelas kontrol.

Untuk pengujian berdasarkan tes akhir dengan menggunakan rata-rata skor diperoleh $t_{\text {hitung }}=1,78$ dan $t_{\text {tabel }}=1,67$ maka, $H_{0}$ ditolak dan hipotesis satu $\left(\mathrm{H}_{1}\right)$ diterima. Artinya terdapat perbedaan hasil belajar antara siswa yang diberi perlakuan pembelajaran melalui model pembelajaran AIR (Auditory, Intellectualy, Repetition) dan siswa yang diberi perlakuan pembelajaran melalui model pembelajaran Konvensional.

\section{Pembahasan}

Penelitian ini bertujuan untuk mengetahui perbedaan model pembelajaran AIR dengan model pembelajaran konvensional terhadap hasil belajar fisika. Model Pembelajaran AIR (Auditory, Intellectualy, Repetition) merupakan suatu model pembelajaran yang menekankan pada kegiatan belajar siswa, dimana siswa secara aktif membangun sendiri pengetahuannya secara pribadi maupun kelompok, dengan cara mengintegrasikan ketiga aspek tersebut. Dari penelitian yang telah dilakukan, untuk mengukur kemampuan siswa digunakan pretest dalam bentuk pilihan ganda yang terdiri dari 20 nomor, bentuk tes ini telah divalidasi oleh validitas ahli yang ditekankan pada validitas isi hasil Belajar.Pada penelitian ini, siswa yang menjadi sampel penelitian diberikan tes awal (pretest) dan tes akhir (posttest). Tes awal yang diberikan pada kelas kontrol dan kelas eksperimen bertujuan untuk mengetahui apakah kemampuan awal kedua kelas sama atau tidak. Sedangkan tes akhir diberikan untuk mengetahui apakah terdapat perbedaan hasil belajar di kedua kelas tersebut.

Perhitungan atau pengolahan data dengan menggunakan Microsoft Excel sehingga didapatkan hasil pengujian normalitas untuk pretest pada kedua kelas diperoleh pada kelas eksperimen $\chi_{\text {hitung }}^{2}=1,31$ dan kelas kontrol $\chi_{\text {hitung }}^{2}=1,29 \quad$ sedangkan $\chi_{\text {tabel }}^{2}=5$,99dimana $\chi_{\text {hitung }}^{2}<\chi_{\text {tabel }}^{2}$ dan untuk posttest pada kelas eksperimen $\chi_{\text {hitung }}^{2}=2,08$ dan kelas kontrol $\chi_{\text {hitung }}^{2}=1,87$, hal ini 
menunjukkan bahwa data berdistribusi normal pada taraf nyata 0,05 . Hasil dari pengujian homogenitas dengan menggunakan uji Feisher (uji F). Pengujian homogenitas varians pada kelas ekperimen dan kelas kontrol diperoleh tes awal adalah 1,43 dan tes akhir 1,19 dengan kriteria pengujian $F_{(1-\alpha)(n-1)}<F<F_{\left(\frac{1}{2} \alpha\right)\left(n_{1}-1\right)\left(n_{2}-2\right)}$ yang menunjukkan kedua kelas yang dijadikan sampel berasal dari populasi yang homogen, baik itu dari kelas ekperimen maupun kelas kontrol .

Pengujian hipotesis dilakukan pada taraf nyata 0,05 dan $\mathrm{dk}=49$ diperoleh pengujian hipotesis pada tes awal adalah $t_{\text {hitung }}=0,27$ dan $t_{\text {tabel }}=1,67$ maka $\mathrm{H}_{0}$ diterima dan hipotesis $\mathrm{H}_{1}$ di tolak, artinya tidak terdapat perbedaan hasil belajar antara kelas ekperimen dan kelas kontrol. Pada pengujian tes akhir di peroleh $t_{\text {hitung }}=1,78$ dan $t_{\text {tabel }}=1,67$ maka $\mathrm{H}_{0}$ di tolak dan $\mathrm{H}_{1}$ diterima, artinya terdapat perbedaan hasil belajar antara siswa yang diberi perlakuan melalui model pembelajaran (Auditory, Intellectualy, Repetition) AIR dan model pembelajaran Konvensional.Hasil penelitian ini memperlihatkan adanya perbedaan hasil belajar antara siswa yang mengikuti model pembelajaran (Auditory, Intellectualy, Repetition) AIR dan model pembelajaran Konvensional.

Hasil analisis data untuk tes akhir hasil belajar fisika, skor rerata dan standar deviasi tes akhir pada kelas eksperimen yang menggunakan model pembelajaran Auditory Intellectualy Repetition (AIR) dan kelas kontrol yang menggunakan model pembelajaran Konvensional. Pada kelas eksperimen yaitu 12,46 dan kelas kontrol yaitu 9,44 serta standar deviasi yaitu 6,08 . Hal ini menunjukkan tes hasil belajar antara kedua kelas berbeda setelah mendapatkan perlakuan.

Perbedaan hasil belajar ini terjadi dari perolehan data tersebut untuk kelas ekperimen karena siswa diterapkan model pembelajaran AIR (Auditory, Intellectualy, Repetition) melalui proses pelaksanaan kegiatan belajar mengajar yaitu siswa mendengarkan atau menyimak arahan dari guru (Auditory), lalu siswa secara berpasangan melakukan demontrasi untuk memecahkan masalah dan siswa mengerjakan lembar permasalahan secara individu serta siswa melakukan diskusi untuk mengidentifikasi atau menyelidiki suatu masalah yang dimana nantinya siswa mengajukan pertanyaan (Intellectualy) selesai proses belajar mengajar guru memberikan kuis pada setiap akhir pelajaran (Repetition). Pada kelas kontrol siswa diterapkan model pembelajaran Konvensional yang mana umumnya dilakukan metode caramah yaitu guru memberikan dan menerangkan materi pelajaran dan siswa mengajukan pertanyaan mengenai materi yang dijelaskan atau guru lebih efektif dibandingkan siswa yang hanya menerima sehingga suasana belajar cenderung monoton yang mengakibatkan pelajaran fisika itu sulit dipelajari.

Hasil belajar pada kelas eksperimen lebih tinggi dikarenakan adanya perbedaan perlakuan yang diberikan terhadap kedua kelas.Karena pada kelas eksperimen diberikan perlakuan dengan model pembelajaran AIR sedangkan pada kelas kontrol diberikan perlakuan dengan model pembelajaran konvensional.Dengan demikian, siswa pada kelas eksperimen tingkat pemahaman lebih tinggi dibanding kelas kontrol karena siswa dituntut untuk secara aktif membangun sendiri pengetahuannya secara pribadi maupun kelompok. Karena, dengan siswa yang aktif dan menemukan sendiri apa yang mereka pelajari dan menggabungkan dengan pemahaman mereka, maka siswa cenderung mengingat dan memahami tentang konsep yang diberikan. Dengan cara pembelajaran seperti ini maka siswa menjadi pusat pembelajaran sedangkan guru hanya sebagai fasilitator.

Model pembelajaran AIR (Auditory, Intelletualy, Repetition) merupakan suatu model pembelajaran yang menekankan pada kegiatan belajar siswa, dimana siswa secara aktif membangun sendiri pengetahuannya secara pribadi maupun kelompok dengan cara mengintegrasikan ketiga aspek tersebut. Dengan menerapkan AIR secara berulang-ulang pada materi besaran, satuan, dimensi dan pengukurannya, kemampuan siswa dalam hasil belajarnya meningkat. Dimana awalnya siswa 
masih merasa bingung dan banyak bertanya dalam melakukan praktikum, terutama dalam materi pengukuran menggunakan alat jangka sorong dan mikrometer sekrup dalam mengukur suatu benda setelah diberikan penjelasan cara mengunakan dan mengukur alat tersebut siswa terlihat lebih mahir bahkan mereka menggunakan berbagai macam benda dan memahami cara melakukan pengumpulan data. Dalam melakukan praktikum pengukuran siswa lebih banyak mengemukakan pendapatnya dan mengajukan pertanyaan ataupun secara berkelompok dalam menyelesaikan masalah. Selanjutnya pada materi besaran, satuan dan dimensi siswa sudah mengetahui pengertiannya hanya saja pada menentukan dimensi harus diberikan lambang siswa bertanya-tanya tetapi setelah diberikan contoh siswa sudah lebih memahaminya. Bahkan pada akhir pembelajaran siswa diberikan kuis dalam waktu beberapa menit mereka lebih cepat menjawab pertanyaan tersebut, sehingga dengan model pembelajaran AIR (Auditory, Intellectualy, Repetition) siswa sudah lebih aktif dan kreatif dalam memecahkan masalah dan berani mengemukakan pendapatnya dalam kelompok.

Tentang eksperimentasi model pembelajaran Auditory Intellectualy Repetition (AIR) terhadap prestasi Belajar matematika ditinjau dari karakter belajar siswa kelas VII SMP Negeri Se Kecamatan Kaligesing menemukan bahwa pada analisis tahap awal yang dilakukan dalam penelitian ini diperoleh data yang menunjukkan bahwa kelas eksperimen dan kelas kontrol dalam keadaan seimbang[4]. Hasil uji keseimbangan yang dilakukan dengan uji $t$ diperoleh diperoleh $F_{\text {hitung }}$ $=0.142$ dengan taraf signifikan 0.05 diperoleh $\mathrm{F}_{\text {tabel }}=1.960$ karena $\mathrm{F}_{\text {tabel }}=-1.960<\mathrm{F}_{\text {hitung }}<$ $F_{\text {tabel }}=1.960$, artinya kedua kelompok berasal dari populasi yang memiliki kemampuan awal sama. Setelah dilakukan pembelajaran pada kelas eksperimen dengan menggunakan model pembelajaran AIR (Auditory, Intellectualy, Repetition) dan kelas kontrol dengan menggunakan model pembelajaran Konvensional, selanjutnya dilakukan uji hipotesis. Hasil penelitian dengan $a=0.05$, menyimpulkan bahwa: $\mathrm{F}_{\text {obs }}=17.018>\mathrm{F}_{\text {tabel }}=$ 4.08 sehingga Ho ditolak yang berarti bahwa terdapat perbedaan prestasi belajar siswa dengan menggunakan model pembelajaran AIR (Auditory, Intellectualy, Repetition) dan model konvensional, dilihat dari rataan marginalnya bahwa model pembelajaran AIR (Auditory, Intellectualy, Repetition) lebih baik dari model konvensional.

Berdasarkan penelitian terdahulu serta dibandingkan dengan hasil penelitian yang dilakukan oleh peneliti dari model tersebut di uji cobakan pada kelas ekperimen dan kelas kontrol pada SMA Negeri 2 Biromaru bahwa diperoleh data untuk tes akhir yang diberikan perlakuan model pembelajaran AIR (Auditory, Intellectualy, Repetition) yaitu 12,46 dan kelas kontrol diberi perlakuan model pembelajaran Konvensional yaitu 9,44. Hal ini membuktikan bahwa model pembelajaran AIR (Auditory, Intellectualy, Repetition) lebih baik dari pembelajaran Konvensional. Adapun dalam kedua model pembelajaran ini tersebut terdapat kelebihan dan kelemahan dimana pada model pembelajaran AIR (Auditory, Intellectualy, Repetition) kelebihannya yaitu siswa lebih aktif dan efektif sedangkan kelemahannya yaitu model ini membutuhkan waktu yang lama. Pada model pembelajaran Konvensional kelemahan dari model ini yaitu siswa cenderung monoton dan hanya menerima materi yang dipelajari.

\section{KESIMPULAN}

Berdasarkan hasil pengolahan dan analisa data penelitian, maka dapat disimpulkan bahwa ada perbedaan hasil belajar fisika antara siswa yang menggunakan model pembelajaran AIR dibandingkan model pembelajaran Konvensional pada siswa kelas $X$ SMA Negeri 2 Biromaru. Hal ini dapat diketahui melalui hasil pengujian hipotesis untuk tes awal dengan menggunakan uji-t dua variabel bebas dimana $\mathrm{t}_{\text {hitung }}=0,27$ dan $\mathrm{t}_{\text {tabel }}=1,67$ maka Ho diterima dimana $\mathrm{t}_{\text {hitung }}<\mathrm{t}$ tabeldan $\mathrm{H}_{1}$ ditolak sedangkan hasil pengujian hipotesis untuk tes akhir dengan menggunakan uji-t dua variabel 
bebas dimana $\mathrm{t}_{\text {hitung }}=1,78$ dan $\mathrm{t}_{\text {tabel }}=1,67$ maka $\mathrm{Ho}$ ditolak dan $\mathrm{H}_{1}$ diterima.

\section{DAFTAR PUSTAKA}

[1] Alhamidi. (2006). Penerapan model pembelajaran AIR (Auditory, Intellectualy, Repetition) dapat meningkatkan kreativitas matematis siswa pada materi geometri dimensi dua pada kelas VIII SMP Negeri 15 Yogyakarta. Pend Matematika. FKIP. [Online] Tersedia. (http://jaul4blog.wordpress.com/2013/02)[5 juni 2014].

[2] Depdiknas. (2004). Penilaian. Jakarta: Departemen Pendidikan Nasional.

[3] Kurniasih, N. (2012). Eksperimentasi model pembelajaran Auditory Intellectualy Repetition (AIR) terhadap prestasi Belajar matematika ditinjau dari karakter belajar siswa kelas VII SMP Negeri Se Kecamatan Kaligesing. Pend. Matematika. FKIP. [online] Tersedia. (http://karyailmiah.um.ac.id/index.php/fkip/article/view/31382)[2 6 agustus 2014].

[4] Udin. (2010). Penggunaan model pembelajaran AIR dalam pembelajaran matematika pada SMA N 1 HARAU. [online] Tersedia. (http://wikipedia.com/course-review-horay)[25 juli 2014]. 